\title{
Efficacy of a herbal drug in treating bovine mastitis
}

\author{
A. L. Aminova ${ }^{1}$, I. F. Yumaguzin ${ }^{1}$, N. R. Subkhankulov', T. A. Sedykh, ${ }^{1,2}$ \\ ${ }^{1}$ Bashkir Research Institute of Agriculture, Ufa Federal Research Centre of the Russian Academy of \\ Sciences, Ufa, Russia \\ ${ }^{2}$ Bashkir State Pedagogical University named after M. Akmulla, Ufa, Russia \\ E-mail:nio_bsau@mail.ru
}

Abstract. Presently, mastitis is being addressed by biologically active agents of plant origin having a bactericidal, viricidal and immune-modulating effect. In this regard, the study of the Raido drug to treat different types of mastitis in lactating cows is of a certain scientific and practical importance. The aim of the study was to determine the efficacy of the Raido herbal drug against serous and catarrhal mastitis in cows during the lactation period. Research methods. Mastitis was detected according to clinical observations, with the results being confirmed by the express diagnosticum Mastidinum or a quick mastitis test. The blood morphological composition in terms of erythrocyte, leucocyte and haemoglobin content was analyzed on a haematological analyzer. Milk samples were examined bacteriologically for the pathogenic microflora. Results. Treating serous and catarrhal mastitis with the Raido herbal drug increased the level of erythrocytes and haemoglobin in recovering cows, reduced their leucocyte content in the peripheral blood, and somatic cells in milk more than doubled. There were no clinical signs of the disease on the fifth day when serving serous mastitis with 5 or $7 \mathrm{ml}$ of the herbal drug intercisternally. Treating catarrhal mastitis with 10 and $12 \mathrm{ml}$ of the drug using the same administration method produced a similar effect on the sixth day. Thus, the optimal dose for daily interstitial administration of serous mastitis was $5 \mathrm{ml}$ and $10 \mathrm{ml}$ for catarrhal mastitis. A comparison of the therapeutic effects of the phytomedicines Raido and Riposol revealed higher efficacy of the daily Raido use in these dosages. Scientific novelty. For the first time, the optimal dosage of the Raido herbal drug for intercisternal administration to cows with serous and catarrhal mastitis was determined; the therapeutic effect of the Raido herbal remedy was detected; a comparative assessment of the Raido and Riposol herbal remedies' effect in the treatment of serous and catarrhal mastitis was made.

Keywords: Raido, herbal medicine, larch, mastitis, lactating cows, treatment, milk.

For citation: Aminova A. L., Yumaguzin I. F., Subkhankulov N. R., Sedykh T. A. Efficacy of a herbal drug in treating bovine mastitis // Agrarian Bulletin of the Urals. 2021. No. 06 (209). Pp. 34-42. DOI: ...

Date of paper submission: 11.01.2021, date of review: 22.01.2021, date of acceptance: 14.04 .2021$.

\section{Introduction}

To date, mastitis remains the most costly problem in the dairy industry from veterinary and economic viewpoints since the food sector does not accept and process milk with antibiotic residues or a high content of somatic cells [1, p. 2212].

The increased incidence of mastitis results from the intensified milk production, larger livestock populations maintained in limited premises, violated machine milking technologies, increased productivity, lower quality feeding, the worsened indoor microclimate, and the spread of infectious diseases [2, p. 119]. Mastitis occurs more frequently in the stall period. This is due to the violation of animal welfare standards, the lack of active exercise. Clinical and subclinical mastitis is identified in more than $50 \%$ of cows [3, p. 187], [4, p. 148]. Purulentcatarrhal mastitis is registered approximately in $10 \%$ of cases during the stable period [5, p. 42].

Milk production requires strict compliance with production technology, adherence to veterinary and sanitary rules of milking, timely disease diagnosis and treatment of cows. The main reasons for poor quality milk are high bacterial contamination and an increased content of somatic cells [6, p. 27].

Currently, mastitis poses a serious problem for dairy farming causing large economic losses. Different diagnostic tests for mastitis are divided into general or phenotypic and specific or genotypic tests.

Milk production requires strict compliance with production technology, adherence to veterinary and sanitary rules of milking, timely disease diagnosis and treatment of cows. The main reasons for poor quality milk are high bacterial contamination and an increased content of somatic cells [6, p. 27].

Phenotypic tests detect general changes that are not specific to any pathogen. General tests for mastitis are constantly being improved. Thus, V. Yu. Komarov and B. L. Belkin (2016) recommend diagnosing cow mastitis comprehensively on the basis of the general clinical condition of the animal, test milking with a visual 
Agrarian Bulletin of the Urals No. 06 (209), 2021

examination of the mammary gland secretion, the milk sample reaction with diagnosticum reagents ("Masttest", "Kenotest", 2 \% solution of "Mastidinum", California mastitis test, etc.) and an additional study of the solid secretion phase [7, p. 100].

Genotypic tests are specific, therefore, confirmatory for the diagnosis of mastitis. They are based on the study of a specific culture based on polymerase chain reaction (PCR). Highly specific and confirmatory diagnostics, such as PCR and nucleotide sequencing, require pure bacterial cultures are the main raw materials [8, p. 77]. Besides, the location and distribution of bacterial colonies are essential for the mastitis diagnosis, since some bacterial species have a diverse life cycle and growth in the milk environment [9]. A considerable amount of domestic and foreign authors have proved that the inflammatory process in the udder of cows are caused by pathogens of different types with the dominant role of coccal microorganisms [10, p. 56], [11, p. 110], [12, p. 47].

Currently, there are different drugs and methods to treat mastitis. The main principle of combating mastitis is the prevention of new infections. Once an infection is detected in the udder, there are four ways to eliminate the disease: spontaneous treatment, culling chronically infected cows, treatment during lactation, and treatment of dry cows. Among these means of fighting infections, antibiotic treatment is the main method of eliminating mastitis and the main reason for using antibiotics in dairy cows. Mastitis is mostly treated with drugs that contain antimicrobial substances, such as antibiotics, sulfonamides, nitrofurans, etc. However, their long-term application evolves the appearance of resistant populations of microorganisms and causes local immunodepression of the mammary gland [13, p. 131].

J. Wilm, et al. (2021) indicate that in terms of pharmacology, drug applicability in mastitis treatment depends on their chemical properties and ability to reach the site of infection with systemic or local application. Thus, severe cases of mastitis caused by gram-negative infections are often addressed using systemic treatment with antibiotics. In contrast, the treatment of mastitis caused by gram-positive bacteria can be carried out with the help of local therapy. Systemic antibiotic treatment may contribute to a higher risk of developing more antibiotic resistance to microorganisms [14, p. 189].

Kh. Sharun, et al. (2021) believe that treating subclinical mastitis with antimicrobial drugs during lactation is rarely economical due to costly treatment [15, pp. 131132]. A. V. Timakov, et al. (2017) draw attention to the fact that timely diagnosis and treatment of subclinical mastitis can prevent the development of clinical mastitis and prevent atrophy of the mammary gland lobes. At the same time, the mastitis treatment efficacy is very unstable due to drug-resistant strains of opportunistic microflora, including the components that are part of many antimastitis drugs [16, p. 19].

Thereby, there is a search for new medicines, including those of plant origin. Their local application will help avoid the systemic use of antibiotics, especially in the early stages of mastitis development. Thus, a comprehensive scheme to prevent bovine mastitis has been developed using environmentally friendly preparations Bioinfuzin and Histogen based on Leucea safflower. The treatment carried out according to the scheme differs favorably from traditional methods of mastitis prevention and treatment in terms of therapeutic and preventive efficacy and the obtained indicators [17, pp. 145-146]. There are results of experimental and clinical trials indicating that the Raido remedy obtained by water extraction from larch has a number of advantages in the treatment of mastitis in cows [18, p. 2]. It was found that the main groups of water-extractive substances in coniferous trees are: water-soluble lignans/lignins having a polyphenolic nature, tannins and their high-molecular derivatives (tannin agents), substances of a carbohydrate nature [19, pp. 194-195]. Hence, the study of herbal remedies for serous and catarrhal mastitis in cows is of a certain scientific and practical significance.

The aim of the work is to determine the efficacy of the Raido phytomedicine in treating serous and catarrhal mastitis of cows during the lactation period. The given aim was achieved by the following objectives: to determine the optimal dosage of the Raido herbal remedy for intercisternal administration to cows with serous and catarrhal mastitis; to determine the therapeutic effect of using the Raido drug; to make a comparative assessment of the effect of using the Raido and Riposol phytomedicines in the treatment of serous and catarrhal mastitis.

\section{Methods}

The efficacy of the Raido phytomedicine was conducted in two farms of the Republic of Bashkortostan (the breeding farm Alga in the Krasnokamsky district and the Federal State Unitary Enterprise Ufimskoye in the Ufa district) in 2019-2020. The research target was cows, a total of 211 black-and-white dairy cows (of first and second lactation). The experiments involved 137 heads with clinical signs of the initial stage of acute serous mastitis and 74 heads with catarrhal mastitis.

With serous mastitis in cows, milk contained flaky particles and clots; the mammary glands were swollen, the infected quarter was hyperemic, enlarged and hard. Milk passed with difficulty, and painfully, milk yield was decreasing.

With catarrhal mastitis, inflammation was mainly detected in the mammary ducts (small pea-sized indurations in a quarter detected on palpation) or less often in the udder alveoli. Milk was watery and greyish with an admixture of mucus and casein flakes. They were secreted at the beginning of milking if the inflammatory process was in the milk cistern and large milk ducts and throughout milking if catarrhal inflammation had affected udder alveoli. Sometimes cows were easily tired; they had a slightly higher body temperature and no appetite. Both types of mastitis mainly occurred in the first month of milking, especially immediately after calving or at the beginning of milking.

The studied farms had similar animal maintenance and feeding conditions. The main winter diet of dairy cows included: hay, silage or haylage, grass chop, and concentrates. 
On average, cows consumed 3.0-3.2 kg of dry matter per $100 \mathrm{~kg}$ of live weight.

The research scheme for determining the optimal dosage of the Raido phytomedicine is given in table 1 .

Detecting the therapeutic effect of the Raido herbal drug was carried out based on the regimen presented in table 2 .

The sick cows were divided into experimental and control groups. The experimental cows with serous mastitis were administered $5.0 \mathrm{ml}$ of Raido, cows with catarrhal mastitis $-10.0 \mathrm{ml}$ of Raido. The drug was injected intracisternally once a day.

The main treatment regimen used in animals of the control group. The control group cows with both forms of mastitis were treated with mastisan-A antibiotics with bicillin. $10.0 \mathrm{ml}$ of the heated drug mastisan-A was injected into the udder cistern daily, bicillin-5 (1500 TU) by a single intramuscular injection at the rate of $10 \mathrm{TU}$ per $1 \mathrm{~kg}$ of animal body weight.

A comparative description of the therapeutic effects of the Raido and Riposol phytomedicines is given in table 3 .

80 dairy cows with serous and catarrhal mastitis were selected to determine the efficacy of the herbal drug Raido.
The animals were divided into four groups. Two experimental groups were administered intra-cisternally Raido at a dose of $5.0 \mathrm{ml}$ (in case of clinical mastitis) and $10.0 \mathrm{ml}$ (in case of catarrhal mastitis) once a day until recovery. Similarly, the two control groups were administered the Riposol herbal remedy intracisternally.

Mastitis was diagnosed by a cytological method based on gelation in the interaction of udder secretions with a surfactant (domestic express-diagnosticum mastidin).

Optionally, a sediment test was conducted for milk taken from all quarters or only from those with a positive reaction to mastitis obtained by a rapid mastitis test (RMT).

For this examination, $10-15 \mathrm{ml}$ of milk were collected from all quarters into test tubes at the end of milking. Each tube carried a label with the cow's name (number) and the time of sampling. The test tubes were placed in a cold place $\left(4-10^{\circ} \mathrm{C}\right)$ for $16-18$ hours. Then they were assessed in terms of milk colour, the sediment presence, the thickness and nature of the cream layer.

The milk collected from the mastitis-affected quarter has sediment; in some cases, it becomes watery, the cream layer decreases, being viscous, slimy, flaky.

Table 1

Determining the optimal dosage of the Raido herbal medicine

\begin{tabular}{|c|c|c|c|c|c|c|c|}
\hline \multicolumn{4}{|c|}{ Serous mastitis } & \multicolumn{4}{|c|}{ Catarrhal mastitis } \\
\hline 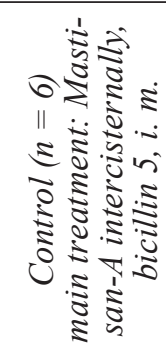 & 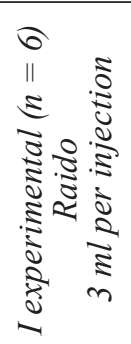 & 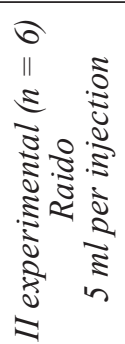 & 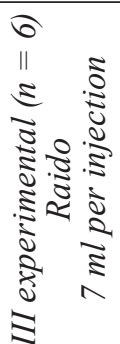 & 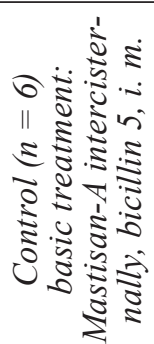 & 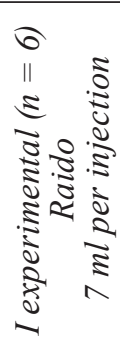 & 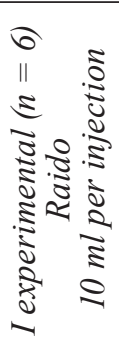 & 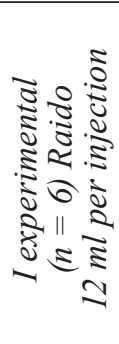 \\
\hline
\end{tabular}

The studied parameters: morphological composition of blood, the content of somatic cells in milk, the number of the Raido herbal drug until complete recovery of cows, days

Table 2

Determination of the therapeutic effect of the Raido herbal medicine

\begin{tabular}{|c|c|c|c|}
\hline \multicolumn{2}{|c|}{ Serous mastitis } & \multicolumn{2}{|c|}{ Catarrhal mastitis } \\
\hline $\begin{array}{c}\text { I control group }(n=15) \\
\text { mastitis treatment according } \\
\text { to the main regimen: } \\
\text { Mastisan-A intercisternally, } \\
\text { bicillin } 5, i . m .\end{array}$ & $\begin{array}{c}\text { I experimental group } \\
(n=8) 5.0 \text { ml Raido } \\
\text { intercisternally once } \\
\text { a day }\end{array}$ & $\begin{array}{c}\text { II control group }(n=15) \\
\text { mastitis treatment according } \\
\text { to the main regimen: } \\
\text { Mastisan-A intercisternally, } \\
\text { bicillin } 5, i . m .\end{array}$ & $\begin{array}{c}\text { II experimental group } \\
(n=8) 10.0 \text { ml Raido } \\
\text { intercisternally } \\
\text { once a day }\end{array}$ \\
\hline
\end{tabular}

Table 3

Comparative characteristics of the therapeutic effects of the Raido and Riposol phytomedicines

\begin{tabular}{|c|c|c|c|}
\hline \multicolumn{2}{|c|}{ Serous mastitis } & \multicolumn{2}{|c|}{ Catarrhal mastitis } \\
\hline $\begin{array}{l}\text { I experimental group } \\
(n=20) \\
\text { mastitis treatment with } \\
\text { Riposol }\end{array}$ & $\begin{array}{c}\text { II experimental group } \\
(n=20) \\
5.0 \mathrm{ml} \text { of Raido intercister- } \\
\text { nally once a day }\end{array}$ & $\begin{array}{l}\text { I experimental group } \\
(n=20) \\
\text { mastitis treatment with } \\
\text { Riposol }\end{array}$ & $\begin{array}{l}\text { II experimental group } \\
(n=20) \\
10.0 \mathrm{ml} \text { of Raido intercis- } \\
\text { ternally once a day }\end{array}$ \\
\hline The studied indicators: th & & & ays), the number of somatic \\
\hline
\end{tabular}




\section{Agrarian Bulletin of the Urals No. 06 (209), 2021}

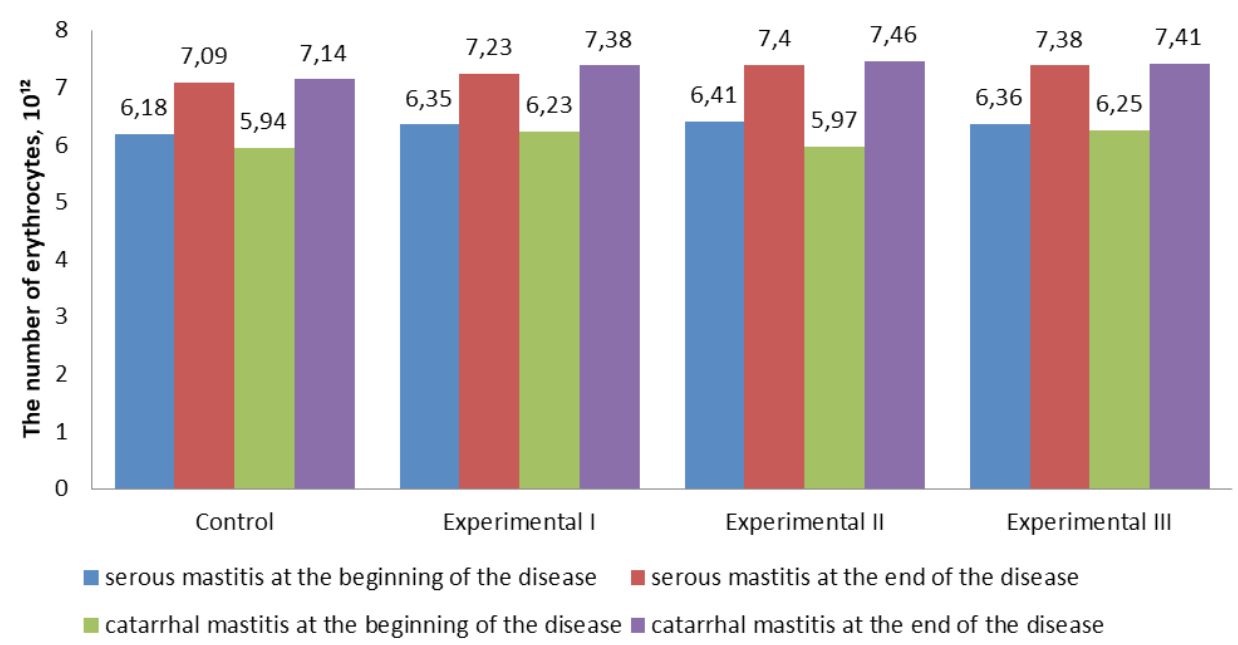

Fig. 1. Changes in the number of erythrocytes in the peripheral blood of cows with different forms of mastitis when using the Raido phytomedicine, $10^{12} / l$

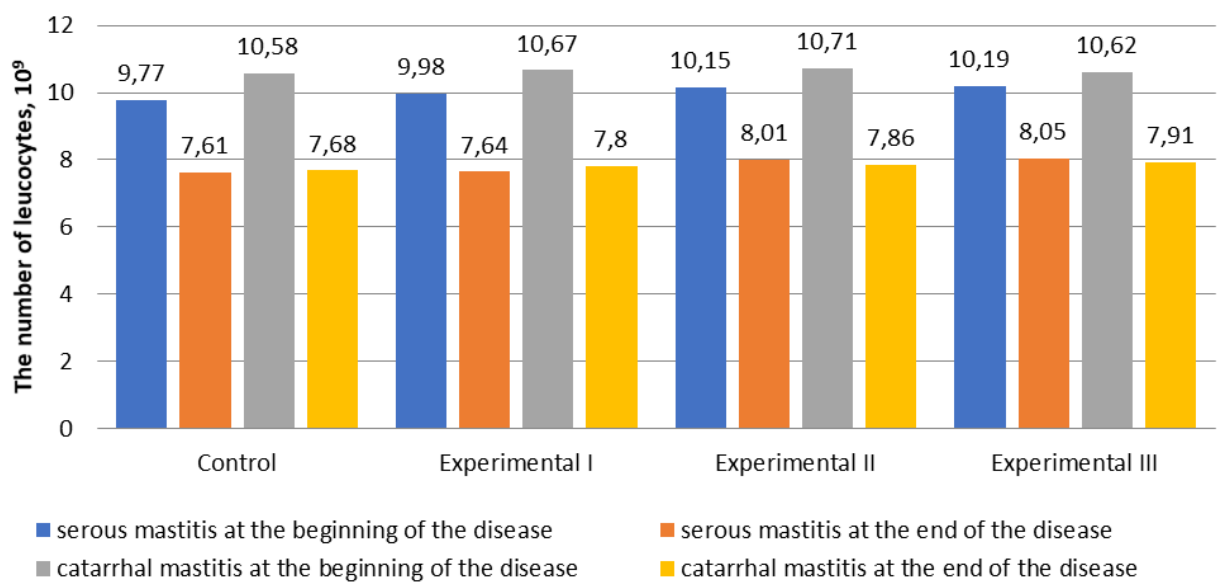

Fig. 2. Changes in the number of leucocytes in the peripheral blood of cows with different forms of mastitis when using the Raido phytomedicine, $10^{9} / 1$

The Raido product (produced by Agrovate LLC) is bin on the first day of clinical signs, on the 5th day of a water-dispersed extract from larch wood and bark, the therapeutic value of its extractives is represented by polyphenols, flavonoids, lignins, tannins, dihydroquercitin, arabinogalactan.

To treat cows with clinical and catarrhal mastitis, Raido was administered intracisternally at a dose of $5.0 \mathrm{ml}$ and $10.0 \mathrm{ml}$, respectively, once a day after preliminary taking milk from the affected udder lobe.

Riposol is an aqueous extract of larch, Siberian cedar and fir wood obtained by bioresonance extraction. The drug includes a complex of active substances, such as arabinogalactin, phenolic compounds (derivatives of cinnamic acid, coniferyl, quercetin, dihydroquercetin, kaempferol, traces of other flavonoids and phenolic acids) and sesquiterpenes, which exhibit immunomodulatory, antitumor, antimicrobial, gastroprotective, and antiinflammatory properties [11, p. 118].

After introducing the herbal remedy, physiological containers of the udder were lightly massaged for even drug distribution. The animals under the experiments were monitored daily until they were completely cured.

Blood samples were taken from the jugular vein into test tubes with heparin (blood stabilization) to determine the content of erythrocytes, leucocytes and haemogloserous mastitis and on the 6th day of catarrhal disease. Haematological studies were performed under the clinical diagnostic laboratory. Morphological composition of blood was studied with the Beckman Coulter LH-500 Hematology analyzer (USA). The number of erythrocytes, haemoglobin and leucocytes was detected by the Coulter method (flow cytometry).

The phytomedicine efficacy was assessed 5-7 days after undergoing the therapy based on reduced clinical signs, a negative reaction of milk with RMT, a sediment test, calculation of somatic cells in the Goryaev chamber and a control bacteriological study of milk samples for the presence of pathogenic microflora.

Biometric data were processed using the Microsoft Excel 2010 software package.

\section{Results}

The optimal therapeutic dose of Raido to treat cows with mastitis and the time necessary for complete recovery were determined comprehensively, taking into account blood morphological composition and protein fractions of blood serum.

The content of erythrocytes, leucocytes and haemoglobin at the beginning and the end of the disease is shown in fig. 1-3. 


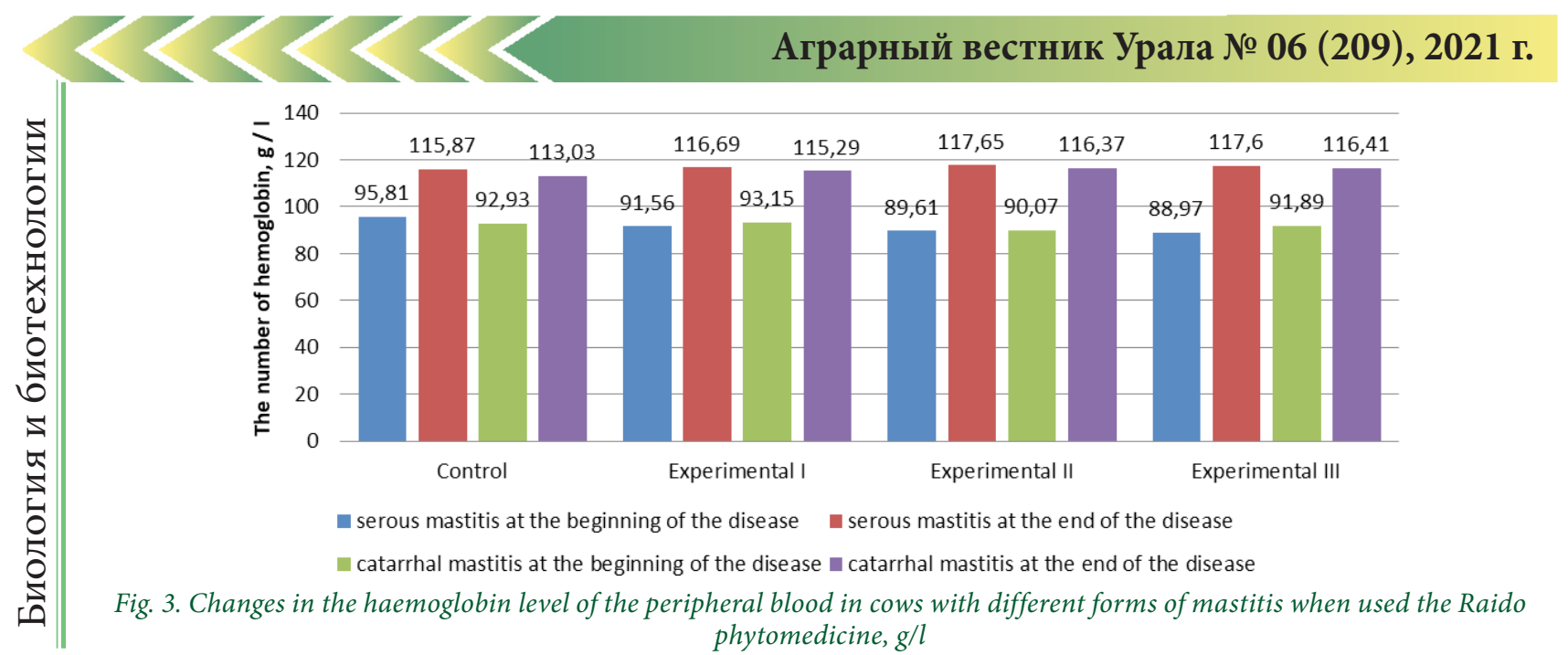

Examination of the erythrocyte number in the animal blood did not reveal significant intergroup differences. The erythrocyte content at the beginning of the disease was within the lower limit of the physiological standard. It ranged within $6,18-6,4110^{12} / 1$ in cows with serous mastitis. By the end of the disease, this indicator increased by $12.83 \%$ in the control group, $12.17 \%$ in the first experimental group, $13.37 \%$ in the second experimental group, $13.82 \%$ in the third experimental group. In the catarrhal mastitis treatment, the erythrocyte number was slightly lower at the beginning of the disease than the same indicator in animals with serous mastitis. It was $5,94-6,2510^{12} / 1$, and changed as follows: by the end of the disease, it was higher by $16.08 \%$ in the control group, $15.58 \%$ in the first experimental group, $19.97 \%$ in the second experimental group, $15.65 \%$ in the third experimental group. The increase in the number of erythrocytes in the peripheral blood is associated with better metabolic processes in the body of recovering cows.

During the studies, there were no significant intergroup differences in the leucocyte content in the peripheral blood of cows. At the beginning of the disease, the number of white blood cells was within the upper limit of the physiological standard and ranged 9,77-10,19 10\%/ in animals with serous mastitis. By the end of the disease, this indicator increased by $22.10 \%$ in the control group, $20.44 \%$ in the first experimental group, $21.08 \%$ in the second experimental group, $21.00 \%$ in the third experimental group. In the catarrhal mastitis treatment, the leucocyte level at the beginning of the disease was slightly higher than the same indicator in animals with serous mastitis. It was $10,58-10,7110^{9} / 1$ and changed as follows: by the end of the disease, it was higher by $27,41 \%$ in the control group, $26,00 \%$ in the first experimental group, $26,61 \%$ in the second experimental group, $26,45 \%$ in the third experimental group. The lower leucocyte content by the end of the disease is due to the reversal of the inflammatory process and the improvement of metabolic processes in the cows' udder tissues.

The studies did not find considerable intergroup differences in the blood haemoglobin level. At the beginning of the disease the amount of hemoglobin was within the lower limit of the physiological standard. It

was within $88.97-95.81 \mathrm{~g} / \mathrm{l}$ in cows with serous mastitis. By the end of the disease, this indicator increased by $17.31 \%$ in the control group, $21.53 \%$ in the first experimental group, $23.81 \%$ in the second experimental group, $24.34 \%$ in the third experimental group. When treating the catarrhal mastitis, the haemoglobin level was lower than the same indicator in animals with serous mastitis at the beginning of the disease. It was $90.07-93.15 \mathrm{~g} / \mathrm{l}$, and changed as follows: by the end of the disease, it was higher by $17.78 \%$ in the control group, $19.20 \%$ in the first, $22.60 \%$ in the second, $21.06 \%$ in the third experimental groups. The higher haemoglobin level results from better oxidation-reduction processes in the body of recovering animals.

At the beginning of the disease, the number of somatic cells in milk in cows with serous mastitis was 965.1 thousand $/ \mathrm{ml}$ in the control group. In the experimental groups, this indicator ranged from 976.1-981.5 thousand $/ \mathrm{ml}$. Upon recovery, the number of somatic cells significantly $(\mathrm{P}<0.01)$ decreased by more than two times and amounted to 403.2 thousand $/ \mathrm{ml}$ in the control group, where the standard treatment regimen was used; it was 468.6 thousand $/ \mathrm{ml}$ in the first experimental group, where $3 \mathrm{ml}$ of the Raido herbal medicine per intercisternal injection was used; 415.1 thousand $/ \mathrm{ml}$ in the second experimental group, with $5 \mathrm{ml}$ of phytomedicine, 416.4 thousand $/ \mathrm{ml}$ in the third experimental group, where a single dosage was $7 \mathrm{ml}$.

The number of somatic cells in the milk of animals with catarrhal mastitis was 975.4 thousand/ml in the control group, $976.3-980.1$ thousand $/ \mathrm{ml}$ in the experimental groups at the beginning of the disease On recovery, the number of somatic cells changed in the same way as in serous mastitis, that is, it was halved and amounted to 421.1 thousand $/ \mathrm{ml}$ in the control group with the standard treatment regimen, 479.7 thousand $/ \mathrm{ml}$ in the first experimental group with $7 \mathrm{ml}$ of the phytomedicine used; 422.1 thousand $/ \mathrm{ml}$ in the second experimental group with $10.0 \mathrm{ml}$ of the drug applied; 421.8 thousand $/ \mathrm{ml}$ in the third experimental group, where $12 \mathrm{ml}$ of Raido was administered intercisternally.

Thus, when recovering the milk of dairy cows, treated by a single daily intercisternal administration of the Raido phytomedicine, had a twofold decrease in the number of somatic cells. 
Agrarian Bulletin of the Urals No. 06 (209), 2021

Table 4

The optimal therapeutic dose of Raido to treat cows with mastitis

\begin{tabular}{|l|l|c|c|c|}
\hline Mastitis type & Experimental groups & $\begin{array}{c}\text { The number of } \\
\text { cows, heads }\end{array}$ & $\begin{array}{c}\text { The drug dosage per } \\
\text { 1 injection in ml }\end{array}$ & $\begin{array}{c}\text { The number of injections } \\
\text { until full recovery }\end{array}$ \\
\hline \multirow{4}{*}{ Serous } & Control & 6 & - & 5 \\
\cline { 2 - 5 } & Experimental I & 6 & 3 & 6 \\
\cline { 2 - 5 } & Experimental II & 6 & 5 & 5 \\
\cline { 2 - 5 } & Experimental III & 6 & 7 & 5 \\
\hline \multirow{4}{*}{ Catarrhal } & Control & 6 & - & 7 \\
\cline { 2 - 5 } & Experimental I & 4 & 7 & 8 \\
\cline { 2 - 5 } & Experimental II & 4 & 10 & 6 \\
\cline { 2 - 5 } & Experimental III & 4 & 12 & 6 \\
\hline
\end{tabular}

Table 5

Therapeutic effect of the Raido herbal drug for different forms of mastitis in lactating cows

\begin{tabular}{|c|c|c|c|c|c|c|c|c|}
\hline \multirow{3}{*}{ 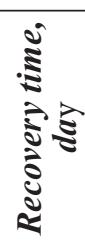 } & \multicolumn{4}{|c|}{ Serous mastitis } & \multicolumn{4}{|c|}{ Catarrhal mastitis } \\
\hline & \multicolumn{2}{|c|}{$\begin{array}{l}\text { I control group } \\
(17 \text { heads })\end{array}$} & \multicolumn{2}{|c|}{$\begin{array}{c}\text { I experimental group } \\
\text { (15 heads })\end{array}$} & \multicolumn{2}{|c|}{$\begin{array}{l}\text { II control group } \\
\text { (10 heads) }\end{array}$} & \multicolumn{2}{|c|}{$\begin{array}{c}\text { II experimental group } \\
\text { (8 heads) }\end{array}$} \\
\hline & $\begin{array}{l}\text { Recovered, } \\
\text { heads }\end{array}$ & $\begin{array}{c}\text { Therapeu- } \\
\text { tic effect, } \\
\%\end{array}$ & $\begin{array}{l}\text { Recovered, } \\
\text { heads }\end{array}$ & $\begin{array}{c}\text { Therapeu- } \\
\text { tic effect, } \\
\%\end{array}$ & $\begin{array}{l}\text { Recovered, } \\
\text { heads }\end{array}$ & $\begin{array}{c}\text { Therapeu- } \\
\text { tic effect, } \\
\%\end{array}$ & $\begin{array}{l}\text { Recovered, } \\
\text { heads }\end{array}$ & $\begin{array}{c}\text { Therapeu- } \\
\text { tic effect, } \\
\%\end{array}$ \\
\hline 1 & - & - & - & - & - & - & - & - \\
\hline 2 & 1 & 5.9 & 1 & 6.7 & - & - & - & - \\
\hline 3 & 3 & 17.6 & 3 & 20.0 & 1 & 10.0 & 1 & 12.5 \\
\hline 4 & 7 & 41.2 & 6 & 40.0 & 1 & 10.0 & 2 & 25.0 \\
\hline 5 & 6 & 35.3 & 5 & 33.3 & 3 & 30.0 & 3 & 37.5 \\
\hline 6 & - & - & - & - & 4 & 40.0 & 2 & 25.0 \\
\hline 7 & - & - & - & - & 1 & 10.0 & - & - \\
\hline
\end{tabular}

The results of determining the duration of treatment when using the optimal therapeutic dose of the Raido phytomedicine are shown in table 4.

The results obtained indicate that daily administration of the Raido herbal medicine had a positive therapeutic effect in curing cows of serous and catarrhal mastitis. Besides, there was a complete absence of clinical signs of serous mastitis and normalization of milk by the number of somatic cells on the fifth day of treatment o with daily administration of Raido in a dose of $5 \mathrm{ml}$ and $7 \mathrm{ml}$. In catarrhal mastitis, the recovery period was 6 days with daily administration of 10 and $12 \mathrm{ml}$ of the phytomedicine. Thus, the conducted study revealed that the optimal dose is $5 \mathrm{ml}$ of the Raido herbal remedy administered daily intercisternally to treat serous mastitis and $10 \mathrm{ml}$ to cure catarrhal mastitis.

Identifying the therapeutic effect of the Raido phytomedicine for different forms of mastitis in lactating cows.

The therapeutic effect was examined by comparing the recovery dynamics of animals treated according to the standard treatment regimen and with the Raido herbal drug in the identified optimal dosage. The results of the recognized therapeutic effect of the Raido phytomedicine for different forms of mastitis in lactating cows are presented in table 5 .

The study revealed the positive dynamics of the reduced clinical signs of acute inflammation in both experimental groups of cows after the first injection of Raido. The first recovered animals among cows with serous mastitis appeared on the second day of treatment
(5.9\% in the control group and $6.7 \%$ in the experimental group), and among animals with catarrhal mastitis on the third day of treatment (10\% in the control group and $12.5 \%$ in the experimental group). While treating serous mastitis, the mammary gland palpation showed lower hyperemia of the inflammation zone and reduced induration of the mammary gland. Clots, flakes, blood admixture gradually disappear in the milk on the 2-3 day of the disease. There was serous exudate with a small proportion of mucus in secretions. Cows regained an appetite and chewing gum; there were yellowish-white excretions from teats only at the beginning of milking on the fourth-fifth days. Further on, the mammary gland function improved, the milk was clean, milk yield increased.

The recovery peak among cows with serous mastitis was observed in the control ( 7 heads $-41.2 \%)$ and experimental ( 6 heads $-40.0 \%$ ) groups on day 4 . Meanwhile, clinical signs in animals of both groups disappeared on the $5^{\text {th }}$ day of treatment. Catarrhal mastitis lasted longer, the peak of recovery was smoothed out. Thus, among cows with this form of mastitis, it occurred on the $6^{\text {th }}$ day of the disease in the control group (4 heads $-40.0 \%$ ) and the $5^{\text {th }}$ day of the disease in the experimental group ( 3 heads $-37.5 \%$ ). Complete recovery was observed on day 7 in the control group, day 6 in the experimental group of cows treated against catarrhal mastitis.

To study the effect of the Raido herbal remedy on the udder microflora, a bacteriological study of the mammary gland secretions of cows of the experimental and control groups was conducted. Sectetion samples were 
taken from the affected lobes in compliance with the rules of asepsis and antiseptics at the beginning of the disease before the introduction of the herbal remedy and during recovery.

The isolated microflora was represented by microorganisms of the Staphylococcus (St. albus, St. aureus), Streptococcus (Str. agalactiae, Str. dysagalactiae, Str. spp.), Escherichia (Esh. coli), Enterobacter (Enter. agglomerans), Klebsiella (Kleb. pneumoniae) genera at the beginning of the disease. After the end of treatment, the previously isolated microflora in secretions of cows of the control and experimental groups was insignificant. The number of mesophilic aerobic and facultative anaerobic microorganisms (QMAFAnM, CFU/g) met the requirements of the Russian State Standard GOST R 52054 "Natural cow's milk-raw materials. Technical requirements".

Determining the efficacy of the Raido and Riposol phytomedicines in treating acute serous and catarrhal mastitis in lactating cows.

A comparative description of the therapeutic effects of the Raido and Riposol herbal drugs is given in table 6 .

As shown in table 6, the complete disappearance of clinical signs of serous mastitis was observed, as a rule, on the 5th day of treatment. Cows of the experimental group II, administered the Raido remedy, recovered in $95 \%$ of cases ( $96 \%$ of udder quarters). When using the Riposol drug, $85 \%$ of cows of the experimental group II got well ( $85.7 \%$ of udder quarters).

The cure of the catarrhal mastitis in the II experimental group occurred, as a rule, on the $6^{\text {th }}$ day of treatment. $95 \%$ of cows (93\% of udder quarters) recovered when using Raido, and $80 \%$ of cows ( $88.5 \%$ of udder quarters) when using Riprosol.

The content of somatic cells in animal milk before and after treatment of clinical and catarrhal mastitis is shown in table 7 .
Table 7 depicts that after treatment with the Raido herbal remedy, the content of somatic cells in the milk of the experimental cows with serous mastitis decreased by 475 thousand $/ \mathrm{ml}(\mathrm{P}<0.01)$, while it was lower by 409.60 thousand $/ \mathrm{ml}(\mathrm{P}<0.05)$ after the Riposol herbal remedy. There was a significant difference $(\mathrm{P}<0.01)$ between the number of somatic cells at the beginning of the disease and after treatment with the mentioned phytomedicines amounted to 504.81 thousand $/ \mathrm{ml}$ and 440.00 thousand $/ \mathrm{ml}$, respectively.

Thus, the research results indicate that the Raido remedy containing larch dihydroquercetin and arabinogalactan contributes to the neutralization of microflora in mastitis-affected quarters. It was expressed by a lower number of somatic cells in milk and a reduced recovery time.

As a result of the calculated economic loss in farms, the daily rejection of milk was about 14000 rubles, with $8 \%$ of cows with mastitis in the herd.

\section{Discussion and Conclusion}

When determining the optimal dosage of the Raido drug, the morphological composition of the blood in cows with serous and catarrhal mastitis was studied in the initial stage of the disease and during recovery. During the treatment, there was a positive dynamics of a higher content of erythrocytes and haemoglobin and a decrease in leukocytosis, which indicates the recovery of the animals.

By the end of the disease, there was a significant (twofold) decrease in the number of somatic cells in cows' milk. It is an important indicator of the herd well-being in terms of mastitis [3, p. 195], [15, p. 47], [15, p. 135].

Since the results obtained for the treatment of serous and catarrhal forms of mastitis with the Raido herbal remedy did not significantly differ in therapeutic effect from the generally accepted treatment regimen for mas-

Table 6

Comparative characteristics of the therapeutic effects of the Raido and Riposol phytomediicines

\begin{tabular}{|c|c|c|c|c|c|c|c|}
\hline \multirow{2}{*}{ Group } & \multicolumn{2}{|c|}{ Number of cows suffering from mastitis } & \multicolumn{4}{|c|}{ Number of recovered cows' } & \multirow{2}{*}{$\begin{array}{l}\text { Recovery } \\
\text { time, days }\end{array}$} \\
\hline & Heads & Udder quarters & Heads & $\%$ & Udder quarters & $\%$ & \\
\hline \multicolumn{8}{|c|}{ Serous mastitis } \\
\hline I experimental & 20 & 24 & 17 & 85 & 21 & 87.5 & \multirow{2}{*}{5} \\
\hline II experimental & 20 & 26 & 19 & 95 & 25 & 96 & \\
\hline \multicolumn{8}{|c|}{ Catarrhal mastitis } \\
\hline I experimental & 20 & 26 & 16 & 80 & 23 & 88.5 & \multirow{2}{*}{6} \\
\hline II experimental & 20 & 27 & 19 & 95 & 25 & 93 & \\
\hline
\end{tabular}

Table 7

The content of somatic cells in cow's milk before and after treatment of clinical mastitis

\begin{tabular}{|c|c|c|c|c|c|c|c|}
\hline \multirow{2}{*}{ Group } & \multicolumn{2}{|c|}{ Number of cows suffering from mastitis } & \multicolumn{4}{|c|}{ Number of recovered cows' } & \multirow{2}{*}{$\begin{array}{l}\text { Recovery } \\
\text { time, days }\end{array}$} \\
\hline & Heads & Udder quarters & Heads & $\%$ & Udder quarters & $\%$ & \\
\hline \multicolumn{8}{|c|}{ Serous mastitis } \\
\hline I experimental & 20 & 24 & 17 & 85 & 21 & 87.5 & \multirow{2}{*}{5} \\
\hline II experimental & 20 & 26 & 19 & 95 & 25 & 96 & \\
\hline \multicolumn{8}{|c|}{ Catarrhal mastitis } \\
\hline I experimental & 20 & 26 & 16 & 80 & 23 & 88.5 & \multirow{2}{*}{6} \\
\hline II experimental & 20 & 27 & 19 & 95 & 25 & 93 & \\
\hline
\end{tabular}


titis with Bicillin 5 and Mastisan A (in the case of serous mastitis treatment, recovery occurred on day 5 , and in the case of catarrhal mastitis - on day 6-7 of therapy), we believe that at the initial stage of the disease, the traditional treatment regimen can be replaced with a daily intercisternal administration of the $5 \mathrm{ml}$ Raido phytomedicine at serous mastitis and $10 \mathrm{ml}$ at catarrhal mastitis. It will prevent the development of microflora resistance to antibiotics and contribute to their absence in dairy raw materials.

The efficacy of the arabinogalactan immunomodulatory properties is shown in the studies of L. A. Nikanova (2020), who found that natural feed additives based on arabinogalactan have an antioxidant and prebiotic effect, contribute to the higher adaptive ability of the body to technological and natural stress factors, increase pathogenetic resistance and correct metabolic processes [20, p. 89]. Arabinogalactan stimulates the growth and activity of lacto-and bifidobacteria, and thanks to this, through the normalization of the intestinal microflora, helps the body's immune system to function more reliably [21, p. 219].

In the conducted scientific and economic experience, the therapeutic effect of herbal remedies Raido (waterdispersed extract from larch wood and bark) and Riposol (water plant extract of larch, Siberian cedar and fir tree wood) based on plant raw materials of coniferous trees were compared, the preparations differ slightly in composition. A comparison of the therapeutic effects of the above-mentioned herbal remedies showed that $95 \%$ of cows with both forms of mastitis recovered with daily intercisternal administration of Raido on day 5-6, while $85 \%$ of cows with serous and $80 \%$ of cows with catarrhal mastitis cured with the use of Riposol. At the same time, the content of somatic cells in the milk decreased by more than two times compared to the beginning of treatment.

The proposed methods of treating serous mastitis in cows using the Raido herbal remedy are more effective in comparison with Riposol treatment proved by a shorter recovery time and a decrease in the number of somatic cells.

Thus, the Raido phytomedicine can be used intercisternally at a dose of $5.0 \mathrm{ml}$ once a day for 5 days to treat the initial stage of acute serous mastitis and at a dose of $10.0 \mathrm{ml}$ once a day for 6 days for the treatment of the initial stage of acute catarrhal mastitis, being an alternative to antibiotics to prevent the development of antibiotic resistance of microflora.

To increase the overall resistance of the body and reduce the incidence of udder inflammation, it is necessary to strictly follow the hygienic and technological rules for animal keeping and milking and to provide the animals with full and balanced feeding.

\section{References}

1. Cobirka M., Tancin V., Slama P. Epidemiology and Classification of Mastitis // Animals (Basel) 2020. No. 10 (12). Article number 2212. DOI: 10.3390/ani10122212.

2. Sychyova T. S., Drozd M. N., Usevich V. M. Vliyanie kormovoy mineral'noy dobavki na profilaktiku mastita $\mathrm{u}$ korov [Influence of a feed mineral supplement on the prevention of mastitis in cows] // Molodezh' i nauka. 2017. No. 6. P. 119. (In Russian.)

3. Tresnitskiy S., Filatova A., Avdeenko V. Effektivnost' parenteral'nogo primeneniya preparatov na osnove tsefalosporinov pri lechenii mastita $\mathrm{v}$ molochnom zhivotnovodstve [Efficiency of parenteral application of preparations based on cephalosporins for mastitis treatment in milk cattle] // Bulletin of science and practice. 2018. Pp. $186-196$. (In Russian.)

4. Novikova S., Sazonov A., Kashkovskaya L. Vliyanie odnokratnogo vvedeniya preparata "Tseftonit ${ }^{\circledR}$ forte" na pokazateli krovi pri lechenii mastita u laktiruyushchikh korov [Influence of a single administration of the drug "Tseftonit $₫$ forte" on blood parameters in the treatment of mastitis in lactating cows] // Effektivnoe zhivotnovodstvo. 2018. No. 1 (140). S. 48-50 (In Russian.)

5. Kiseleva E. V., Tunikov G. M. Ehffektivnost' ispol'zovaniya sovremennykh antimikrobnykh preparatov dlya lecheniya mastita $u$ korov [The effectiveness of the use of modern antimicrobial drugs for the treatment of mastitis in cows] // Vestnik Ryazanskogo gosudarstvennogo agrotekhnologicheskogo universiteta im. P. A. Kostycheva. 2017. No. 4 (36). Pp. 40-44. (In Russian.)

6. Makushev A. E., Larionov G. A., Dmitrieva O. N. Vliyanie profilaktiki mastita na snizhenie mikrobiologicheskoy obsemenennosti i povyshenie ekonomicheskoy effektivnosti proizvodstva moloka korov [Impact of mastitis prevention on reducing microbiological contamination and increasing the economic efficiency of cow milk production] // Agrarian Bulletin of the Urals. 2016. No. 9 (151). Pp. 26-31 (In Russian.)

7. Komarov V. Yu., Belkin B. L. Diagnostika mastita i otsenka effektivnosti provodimoy terapii [Diagnosis of mastitis and assessment of the effectiveness of the therapy] // Innovatsii v APK: problemy i perspektivy. 2016. No. 1 (9). Pp. 97-102. (In Russian.)

8. Chakraborty S., Dhama K., Tiwari R., Yatoo M. R., Khurana S. K., Khandia R., Munjal A., Munuswamy P., Kumar V. A., Singh M., Singh R., Gupta V. K., Chaicumpa W. Technological interventions and advances in the diagnosis of intramammary infections in animals with emphasis on bovine population - a review // The Veterinary quarterly. 2019. No. 39 (1). Pp. 76-94. DOI: 10.1080/01652176.2019.1642546.

9. Lima S. F., Bicalho M. L. B., Bicalho R. C. Evaluation of milk sample fractions for characterization of milk microbiota from healthy and clinical mastitis cows [e-resource] // PLoS One. 2018. No. 13 (3). e0193671. DOI: 10.1371/ journal.pone.0193671 (date of reference: 10.02.2021). 
10. Avduevskaya N. N. Chuvstvitel'nost' zolotistogo stafilokokka, vydelennogo iz vymeni bol'nykh mastitom korov, k kompleksnym preparatam antimikrobnogo deystviya [Sensitivity of Staphylococcus aureus, isolated from the udder of cows with mastitis, to complex antimicrobial drugs] // The Russian journal "Problems of Veterinary Sanitation, Hygiene and Ecology". 2017. No. 3 (23). Pp. 56-59. (In Russian.)

11. Belkin B. L., Komarov V. Yu., Andreev V. B., Andreev S. V. Sravnitel'nyy analiz ehffektivnosti ryada preparatov dlya lecheniya i profilaktiki mastita u korov [Comparative analysis of the effectiveness of a number of drugs for the treatment and prevention of mastitis in cows] // The Russian journal "Problems of Veterinary Sanitation, Hygiene and Ecology". 2017. No. 3 (23). Pp. 109-113. (In Russian.)

12. Pshenichnikova I. L., Sadovnikov N. V. Lechenie i profilaktika subklinicheskogo mastita u korov [Treatment and prevention of subclinical mastitis in cows] // Molodezh' i nauka. 2017. No. 3. P. 47. (In Russian.)

13. Ashenbrenner A. I., Khaperskiy Yu. A., Chekunkova Yu. A., Belyaeva N. Yu. Terapevticheskaya ehffektivnost' preparata "Ekomast" pri ostrom laktacionnom mastite u korov [Therapeutic efficacy of the drug "Ekomast" in acute lactational mastitis in cows] // Veterinariya sel'skokhozyaystvennykh zhivotnykh. 2018. No. 6. Pp. 42-46. (In Russian.) 14. Wilm J., Svennesen L., Eriksen E. Ø., Halasa T., Krömker V. Veterinary Treatment Approach and Antibiotic Usage for Clinical Mastitis in Danish Dairy Herds // Antibiotics (Basel) 2021. No. 10 (2). P. 189. DOI: 10.3390/antibiotics10020189.

15. Sharun Kh., Dhama K., Tiwari R., Gugjoo M. B., Yatoo M. I., Patel S. K., Pathak M., Karthik K., Khurana S. K., Singh R., Puvvala Bh., Amarpal, Singh R., Singh K. P., Chaicumpa W. Advances in therapeutic and managemental approaches of bovine mastitis: a comprehensive review // The Veterinary quarterly. 2021. No. 41 (1). Pp. $107-136$. DOI: $10.1080 / 01652176.2021 .1882713$.

16. Timakov A. V., Timakova T. K. Kompleksnaya terapiya bol'nykh gnoynymi formami mastita korov [Complex therapy of patients with purulent forms of cow mastitis] // Agroindustrial Complex of Upper Volga Region Herald. 2017. No. 3 (39). Pp. 18-21. (In Russian.)

17. Tatarnikova N. A., Zhdanova I. N. Vliyanie preparatov rastitel'nogo proiskhozhdeniya pri klinicheskom mastite korov [The effect of herbal preparations in clinical mastitis of cows] // Izvestiya Orenburgskogo gosudarstvennogo agrarnogo universiteta. 2017. No. 5 (67). Pp. 143-146 (In Russian.)

18. Solodovnikova E. S., Kolesnik A. B., Aminova A. L., et al. Preparat "Raido" dlya profilaktiki i lecheniya mastitov u korov i sposob ego polucheniya ["Raido" for the prevention and treatment of mastitis in cows and how to get it]. Patent RF № 2699723 C1, 09.09.2019. (In Russian.)

19. Ostroukhova L. A., Fedorova T. E., Onuchina N. A., Levchuk A. A., Babkin V. A. Opredelenie kolichestvennogo soderzhaniya ekstraktivnykh veshchestv iz drevesiny, korney i kory derev'ev khvoynykh vidov Sibiri: listvennitsy (Larix sibirica L.), sosny (Pinus sylvestris L.), pikhty (Abies sibirica L.), eli (Picea obolata L.) i kedra (Pinus sibirica du tour) [Determination of the quantitative content of extractive substances from wood, roots and bark of trees of coniferous species of Siberia: larch (Larix sibirica L.), pine (Pinus sylvestris L.), fir (Abies sibirica L.), spruce (Picea obolata L.) and cedar (Pinus sibirica du tour)] // Chemistry of plant raw material. 2018. No. 4. Pp. 185-195. (In Russian.) 20. Nikanova L. A. Vliyanie digidrokvertsetina i arabinogalaktana na promezhutochnyy obmen i rezistentnost' organizma porosyat [Influence of dihydroquercetin and arabinogalactan on intermediate metabolism and resistance of piglets] // The Russian journal "Problems of Veterinary Sanitation, Hygiene and Ecology". 2020. No. 1 (33). Pp. 85-91. (In Russian.)

21. Omarov M. O., Zelkova N. G., Slesareva O. A., Abilov B. T. Vliyanie bioflavanoidov - digokvertsetina i arabinogalaktana na biokhimicheskie pokazateli u vysokoproduktivnykh korov [The effect of bioflavonoids - digoquercetin and arabinogalactan on biochemical parameters in highly productive cows] // Sbornik nauchnykh trudov Krasnodarskogo nauchnogo centra po zootekhnii i veterinarii. 2019. Vol. 8. No. 1. Pp. 216-221. (In Russian.)

\section{Authors' information:}

Albina L. Aminova ${ }^{1}$, candidate of biological sciences, senior researcher, ORCID 0000-0003-2738-4692,

AuthorID 829970; +7 917 440-01-00,albina_ufa@list.ru

Idris F. Yumaguzin ${ }^{1}$, candidate of agricultural sciences, leading researcher, ORCID 0000-0002-5401-0242, AuthorID 158606; +7 905 180-43-82

Niyaz R. Subkhankulov', veterinarian of the animal husbandry department, ORCID 0000-0002-5038-2551, AuthorID 994019; +7 917 367-62-73,niyazsubhankulov@gmail.com

Tatyana A. Sedykh ${ }^{1,2}$, doctor of biological sciences, associate professor, scientific secretary ${ }^{1}$, acting head of the department of genetics and chemistry², ORCID 0000-0002-5401-3179, AuthorID 431877;

+7917778-72-75,nio_bsau@mail.ru

${ }^{1}$ Bashkir Research Institute of Agriculture, Ufa Federal Research Centre of the Russian Academy of Sciences, Ufa, Russia

${ }^{2}$ Bashkir State Pedagogical University named after M. Akmulla, Ufa, Russia 